(f) The service is cost effective. Approximately 130 referrals are seen each year in the schools at a cost to the employing authority of one whole-time senior clinical nurse spectalist.

\section{The future}

We are engaged in the process of recruiting additional staff who will undertake a period of training before joining in providing an expanded service. We are negotlating with a number of schools which have requested our service in the past and are keen to take up the possibility of help in the future, organised along the lines set out above. We feel heartened by the support offered to this innovattve service by our employers, particularly in a time more commonly characterised by contraction rather than expansion of services.

\section{References}

BRUGGEN, P. \& EuOTT, F. (1979) Touch and body language in family therapy. Joumal of Family Therapy. 1, 221229.

Cowmendow, P. \& Eurotr, F. (1975) Sexuality and violence as defences against the pain of death and rejection. Therepeutic Education. 3. 1.

LorTus, M. (1988) Moving to change: action groups in an out patient setting. Journal of Adolescence, 11, 217-229.

T. J. Dyer, Consultant Child and Adolescent Psychiatrist; and F. M. Elliott, Senior Clinical Nurse Specialist, Deeside Child and Adolescent Service, 16 Wepre Drive, Connah's Quay, Deeside, Cluyd CH5 4HA

\title{
A pharmacy-controlled lithium clinic
}

\author{
Mary E. Courtney, Janine A. Acomb and Veronica Lovatt
}

\begin{abstract}
A phamacy-run lithlum cllnic was set up in a district genoral hospltal in order to sove modical stefl time, utillse pharmactst skells and provide on efinclent ltthlum monlioing senvice. Alter one year the clinke wos oveluated in ferms of the control of serum ithlum lovels, the acceptabillty of the arrangements to the patients and the patients' knowlodos of and aftitude fowards lithlum therapy. We sugoest this model of a lithium clinic could be usetully adopted in other poychlatilic doperiments.
\end{abstract}

Patients taking lithium require regular monitoring of their serum lithium levels, and of renal and thyroid function (Schou, 1986). Supervision of lithium treatment may be undertaken by general practitioners, or by specialist hospital services either in general psychiatry out-patient clinics or in specialised lithium clinics. Kehoe \& Mander (1992) in their comparison of lithium monitoring in hospital and in general practice found that patients supervised by their GP had lithium levels checked less frequently and were more likely to experience lithium levels above the therapeutic range.

The therapeutic effectiveness of lithium is obviously dependent on patient compliance, which can be improved by patient education. As lithium is potentially toxic under certain conditions, it is important that patients have accurate and comprehenstve knowledge about its use. Peet \& Harvey (1991) have shown that a patient education programme incorporating videotaped and written material improves patients' knowledge about lithium and their attitude towards lithium therapy. Such an education programme increases the safety of lithium treatment and could well improve compliance.

With the government's Health of the Nation suicide targets and the well-known suicide risk associated with affective disorder, prophylaxds has become an increasingly important area of concern among psychiatrists. The WHO Mental Health Collaborating Centres (1989) in their 
consensus statement on pharmacotherapy of depresstve disorders discuss indications for lithium therapy and the necessity for regular monitoring. They comment: "A special faclity for systematic and regular follow-up of patients and for monitoring plasma lithtum (e.g. an affective disorder clinic) can greatly assist the management of these patients".

Specialised lithium clinics should be able to offer close and skdlled monitoring of lithium therapy with ready access to blood level results, patient education and the opportunity for peer group support. Lithium monitoring may prove expenstve in terms of medical time, and many models of a lithium clinic emphasise the key role of non medical mental health professionals (Fleve \& Peselow, 1987).

A pharmacy-run lithium clinic was developed in Airedale Health Authority in 1991 for the patients of one consultant psychiatrist. Patlents receiving lithium treatment were referred to the pharmacy clinic with a prescription stating the serum lithium range required for that particular patient and any specific recommendations about frequency of blood tests. The normal practice was three monthly serum lithium estimations and yearly tests of renal and thyroid function. Patients attending the lithium clinic were reviewed by the consultant psychiatrist as often as was clinically indicated but at least once a year. The lithium clinic was held in the morning every fortnight, and patients initially attended the pathology department for venepuncture. Immediate lithium estimations were written on each patient's lithium treatment card which the patient then took to pharmacy for discussion with the pharmacist.

The clinic was generally run by the same pharmacist who had records of the patient's previous results. If the new level appeared significantly different, the pharmacist could try to find the reasons why, and also advise a change of dose if necessary. The pharmacist sent details of the lithium level and the change in dose to the consultant and the patient's GP. For new patients there was an opportunity to discuss the treatment with the pharmacist and to see videotaped and written material about lithium.

\section{The study}

After the lithium clinic had been in operation for one year, and before it was extended to take in the patients of other consultants, we conducted an evaluation with the assistance of the medical audit department. The evaluation addressed:

(a) patient satisfaction with the lithium monitoring arrangement and patlent knowledge and attitude towards lithium therapy

(b) the control of lithium levels.

Three questionnaire methods were used; the Lithium Knowledge Test (LKT) and Lithium Attitude Questlonnaire (Peet \& Harvey, 1991) and a Satisfaction Questionnaire (developed for the purpose of this study).

The study included two groups of patients, 15 randomly selected from the pharmacy lithium clinic and 15 taking lithium who were randomly selected from another consultant's out-patient list. For evaluation (a) the medical audit officer administered the three questionnaires. For evaluation (b) we examined serum lithtum levels and relapse rate among the 15 pharmacy lithium clinic attenders in the six months before and after referral to the clinic.

\section{Findings}

The two groups were well matched for age and sex. All patients were recelving lithium prophylaxds for affective disorders.

The arrangements for lithium level monitoring were found to be generally acceptable to both groups. More patients attending the pharmacy clinic compared with those attending the out-patient clinic were satisfied with the information they received about lithium. None of the patients attending the pharmacy clinic felt it was necessary to see a doctor at every visit, and in general they thought it was satisfactory to see the consultant only when indicated by clinical need.

The data collected demonstrate a trend towards the pharmacy clinic patients scoring higher than the out-patients on the Lithium Knowledge Test score (mean LKT score in pharmacy patients $=11.73$, in consultant patients=8.86). With the small numbers involved this difference fails to reach statistical significance. The pharmacy group achieved a mean LKT score similar to patlents who had been in receipt of Peet \& Harvey's (1991) standard education programme (mean LKT score=11.5). 
The LKT hazard score (LKTH) (a score which is a summation of wrong answers to items which are necessary for patients' safety on lithium) was also estimated for each group and a significant difference in favour of the pharmacy group demonstrated (median Hazard score for pharmacy patients $=2$, for consultant out-patients $=5$, using MannWhitney $U$ test, $W=18.0, P=0.0381$ ).

There was no demonstrable difference between the Lithium Attitude Questionnaire scores in the pharmacy clinic attenders and the out-patient attenders.

Serum lithium level control appeared satisfactory in the lithium clinic group although the numbers and timescale were too small and short for a proper statistical evaluation.

\section{Comment}

The results confirm that a pharmacy run lithium clinic is acceptable to patients and suggest that it improves patient knowledge about lithium and the safety of lithium therapy. In addition serum lithium control appeared satisfactory. The monitoring of lithium therapy by the pharmacy represents an appropriate use of pharmacists' skdlls and saves on consultant out-patient time.

\section{Aclonowledgements}

Some of the work presented here was submitted in partial fulfilment of the requirements for the Diploma in Clinical Pharmacy. The Queen's University of Belfast. We would like to thank the patients who participated, Consultant Psychiatrist, Dr Flona McKenzie and Pharmacist, Jacinta Dean.

\section{References}

Fieve R. R. \& Prswow, E. D. (1987) The Hthium clinic. In Depresston and Manta, Modern Lithium Therapy. (ed F. N. Johnson), pp.127-129, Oxford: IRL Press.

KeHOE, R. F. \& MNNDER, A. J. (1992) Lthium treatment: prescribing and monitoring habits in hoopltal and general practice. Brtish Medical Joumal, 804, 552-554.

PEET, M. \& HARVLY, N. S. (1991) Lithium maintenance: 1. A standard education programme for patients. Brtish Joumal of Psychiatry. 168, 197-200.

SchoU. M. (1986) Uthlum treatment: a refresher course. Brttish Joumal of Psychiatry. 149, 541-547.

whO Mentral Hentth Collaboratino Cintras (1989) Pharmacotherapy of depresstve disorders. A consensus statement. Joumal of Affectue Disorders, 17, 197-198.

*Mary E. Courtney, Consultant Psychiatrist, Roundhay Wing, St James's Untuersty Hospital, Leeds LS9 TIF, Janine A. Acomb, Clinical Pharmacist, and Veronica Lovatt, Medical Audit Officer; Atredale General Hospital, Skipton Road, Steeton, West Yorkshire

-Correspondence 